\title{
Trade structure as an enabler of economic growth in Africa
}

\author{
Roseline Tapuwa Karambakuwa \\ Ronney Ncwadi \\ Department of Economics, Faculty of Business and Economic Sciences, \\ Nelson Mandela University, Port Elizabeth, South Africa
}

\section{Keywords}

Concentration, exports, growth, intra-industry, trade, structure

\begin{abstract}
The role of trade structure in determination of economic growth has not been empirically given as much attention as trade openness and trade volume. This is despite the fact that trade openness and trade volume are affected by other influences arising from nontrade growth factors. Hence, we present the role played by trade structure in enabling economic growth in Africa. Using a panel data regression with fixed effects, we regress Gross Domestic Product growth against trade structure variables and other standard explanatory variables for eighteen African countries. Trade structure consists of concentration of trade, intra-industry trade and number of exported goods. To measure concentration of trade, the Hirschman Herfindahl (HHI) index is used while the Grubel-Lloyd (1975) index of intra-industry trade is computed to measure intra-industry trade. Other standard explanatory variables included are gross capital formation, inflation and population growth. We conclude that for African countries, trade structure positively determines economic growth since the variables intraindustry trade and number of exported goods are positively related to Gross Domestic Product. We also conclude that gross capital formation and population growth can lead to economic growth as they are positively related to Gross Domestic Product. Inflation is negatively related to Gross Domestic Product. African countries have a high probability of realising economic growth if they focus on increasing the number of exported products, intra-industry trade, domestic investment and cautiously allowing for population growth. Population growth needs to be treated with caution as it should be sustainable, considering resource availability. It is important for the countries to keep inflation as low as possible as it retards growth. The paper makes original contribution towards empirical literature on the impact of trade structure on economic growth in African countries, an area which has been largely ignored in the past.
\end{abstract}

\section{Introduction}

The role of international trade in determining economic growth is becoming increasingly important with exports contributing 30\% to Gross Domestic Product (GDP) globally in 2018 up from 18\% in 1988 (World Bank, 2019). It becomes therefore important for countries to focus on trade policies to realise increased growth and these include policies on trade structure. Due to increase in economic integration, the trade structures of countries worldwide has been changing. According to Kali , Méndez and Reyes (2007), the changes experienced over the last decades of globalization are more pronounced in terms of the structure of trade than in the volume of trade itself.

However, empirical literature has not given much attention to trade structure despite its increasing importance in determining trade (Rodriguez and Rodrik, 2001). Rather, trade volume, measured in monetary terms and trade openness have been used interchangeably to refer to trade and this has led to inconsistency in definition of trade and methodological problems (Rodriguez and Rodrik, 2001). Further, because trade openness or trade volume are affected by other influences arising from nontrade growth factors such as exchange rate, empirical estimation attempts have failed to isolate the pure impact of trade on economic growth (Rodriguez and Rodrik, 2001). The study of trade structure characteristics could lead to new ways of understanding the trade-growth relationship (Kali et al., 2007).

The purpose of this paper therefore is to present the role played by trade structure in enabling economic growth in Africa. The first hypothesis is that trade structure does not enable economic growth in Africa. The second hypothesis is that the standard explanatory variables do not enable economic growth in Africa. The specific trade structure variables of interest are number of exported goods, concentration of 
trade and intra-industry trade. Gross capital formation, inflation and population growth are the standard explanatory variables. We carry out panel data regression using fixed effects for the period 1988 to 2017 from a sample of eighteen countries in Africa. These countries are Egypt, Gabon, Gambia, Ghana, Guinea, Kenya, Madagascar, Malawi, Mauritius, Morocco, Namibia, Niger, Seychelles, South Africa, Togo, Zimbabwe, Tanzania and Uganda. The countries represent one third of African countries and they are drawn from various African regions.

Our findings suggest that for African countries, trade structure positively determines economic growth, thereby we reject the null hypothesis for trade structure variables intra-industry trade and number of exported products. We also reject the null hypothesis for the standard explanatory variables since they determine GDP growth in different ways. The paper makes significant contribution towards empirical literature as it gives policy implications for trade structure and other standard economic variables on economic growth in Africa.

For the African countries, the mean number of exported goods was on an upward trajectory from 1988 to 2013. However, from 2014 onwards it started to decline as shown in Figure 1. This decline was largely was due to the fall in the price of commodities, the overall appreciation of the US dollar and weaker demand (UNCTAD, 2016).

\section{Figure 1: Number of exported goods by African Economies (HS6 digit Products) 1988-2017}

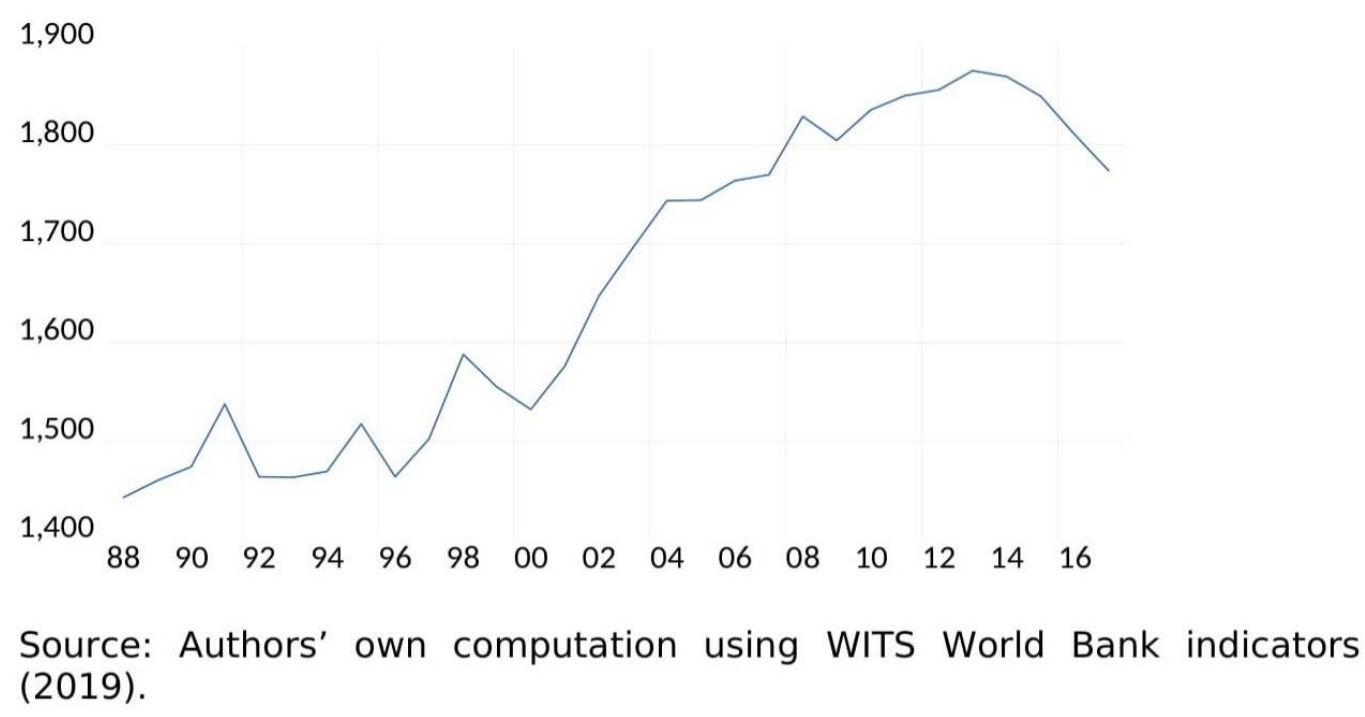

Further, the majority of the countries have low mean trade concentration suggesting that they have a high number of trading partners. Trade concentration gives a reflection of the degree to which a country's trade is concentrated on a small number of trading partners (UNDP, 2015). The Gambia and Niger have the highest mean of trade concentration at 0.32 and 0,39 respectively while Egypt and Uganda have the lowest mean of trade concentration at 0.06. Empirical literature has mixed views about whether concentration of trade is advantageous or not. Trade costs be minimised by high trade concentration and local investment promoted (Frankel, Stein and Wei, 1995).

However, Kali et al., (2007) suggest that low concentration at the industry level might lead to economies of scale, stronger competitive positions, output growth and technology adoption. Countries that are less concentrated tend to be richer, with poor countries being highly concentrated (Bahar, 2016). Countries with more trading partners expand the potential market and adopt foreign technologies leading to greater productivity, hence economic growth (Grossman and Helpmann, 1991). 
Using the Herfindahl-Hirschman ( $\mathrm{HH}$ ) Index of concentration, the trend analysis for the eighteen African countries reflects that concentration of trade has been falling, meaning that there has been a general increase in the number of trade partners over the period. This is presented in Figure 2.
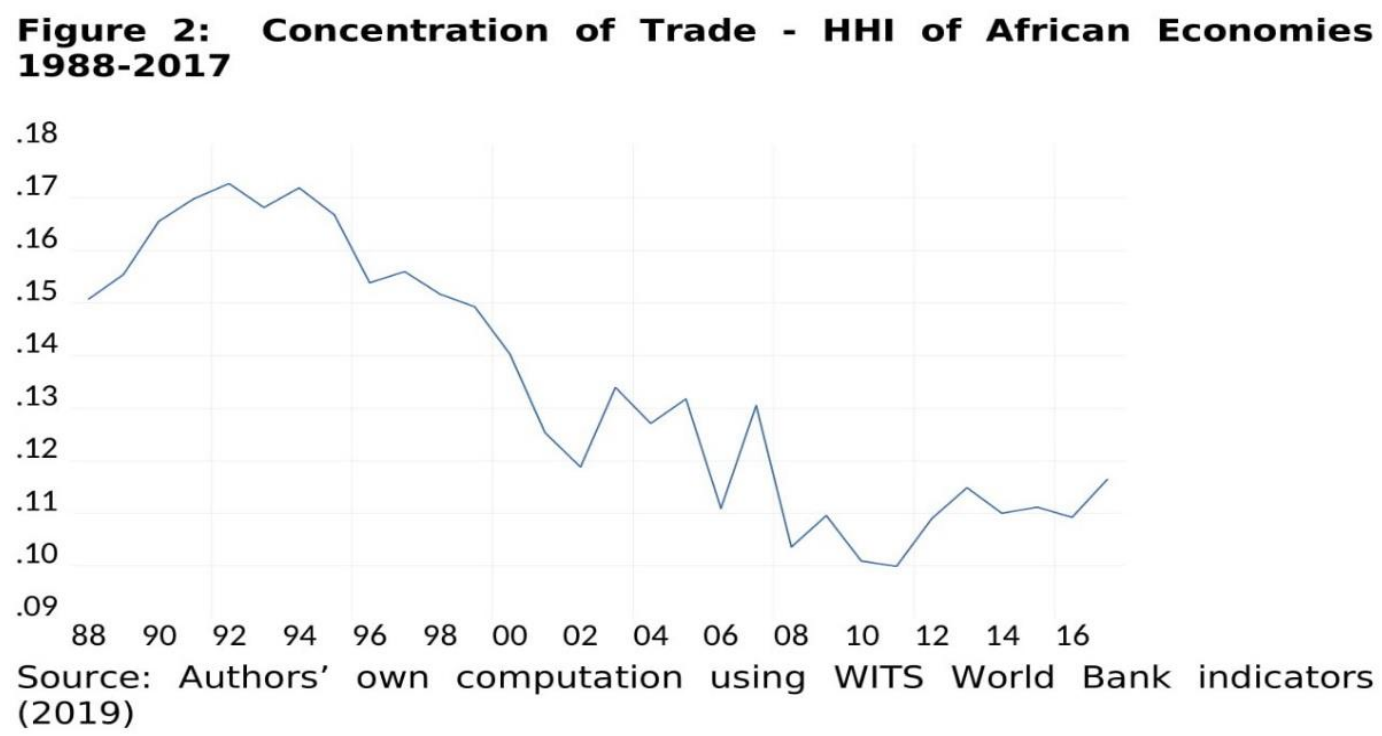

The African countries experienced fluctuations in intra-industry trade, which is trade in essentially the same goods, over the period of study. The lowest intra-industry trade was experienced in 2009 and the highest was experienced between 2000 and 2004. Figure 3 shows these trends using the using GrubelLloyd Intra-industry trade index.

\section{Figure 3: Intra-industry Trade of African Economies 1988- 2017 (using intra-industry trade index)}

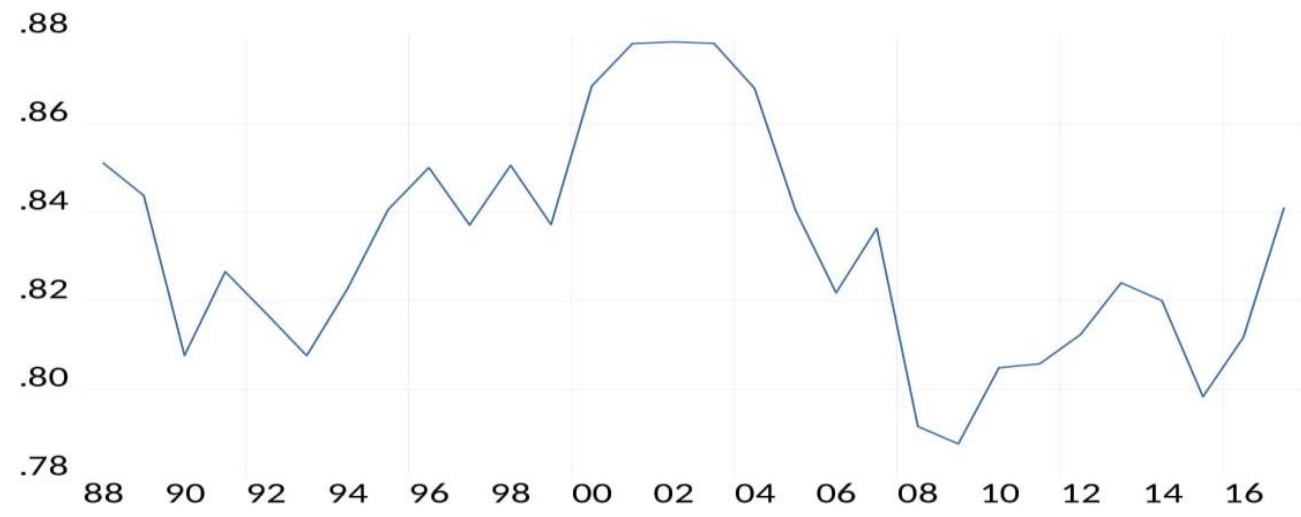

\section{Source: Data from World Bank's World Development Indicators (2019)}

Figure 3 further shows that intra-industry trade fell in 2015, followed by a sharp increase. Balassa (1965) asserts that intra-industry enables countries to have higher productivity growth due to lower costs.

The next section is an analysis of theoretical and empirical literature on trade structure and economic growth, followed by methodology then empirical results and finally discussion and conclusions. 


\section{Literature Review}

In this section, we analyse the literature related to trade structure and growth. We begin with an analysis of theoretical literature, which highlights the conceptual and theoretical aspects of the paper followed by empirical literature which gives previous related research findings clearly showing the research gap for this paper.

\section{Theoretical Literature}

The conceptual aspects for this paper mainly concern intra-industry trade and concentration of trade. Intra-industry trade is the level at which countries trade in essentially the same goods (Salvatore, 2013). The countries with a higher level of intra-industry trade enjoy greater economies of scale in their firms (Sawyer and Sprinkle, 2004). Thus, countries contemplating joining or forming a regional trading block consider adjustment costs and these costs depend on the extent of intra-industry trade (Menon and Dixon, 1996). Balassa (1965) asserts that intra-industry trade entails lower costs of factor-market adjustment, implying that countries with a higher level of intra-industry trade tend to have higher productivity growth. The proportion of intra-industry trade in world trade has steadily grown over the last half century and the scale economies arising lead to more rapid productivity gains and hence faster growth (Krugman, 2015). However intra-industry trade is likely to be larger among industrial economies of similar size and factor proportions (Salvatore, 2013).

Concentration of trade is the degree to which a country engages in international trade with a limited number of partner countries. Trade costs are minimised by concentrating trade, especially costs associated with congestion of insufficient infrastructure, like ports and airports (Frankel et al., 1995). Trade-related public policies that promote local investments become easier and cheaper to implement when trade is concentrated among few partners.

Further, Kali et al., (2007) suggest that low concentration of trade has a positive impact on output growth in that it facilitates technology adoption since the implementation and dissemination of foreign innovations is made easier when more people become familiar with the language and the conventions of these innovations. Because rich countries hold and create more knowledge and have a more diversified economy, better infrastructure and more efficient governments, they are likely to benefit less from trade concentration than do poor countries (Kali et al., 2007).

Theoretically, studies on economic growth derive from the two main competing theories, namely Solow's (1956) neo classical growth theory and Romer's (1986) endogenous growth theory. Even though these theories do not consider trade or trade structure as drivers of economic growth, they explain another variable in this paper namely gross capital formation as a determinant of economic growth.

According to Solow (1956), an economy grows as a result of increasing input of capital and labour. The impact on output per worker resulting from capital accumulation will continuously decline due to diminishing returns caused by population growth and the depreciation rate. In the long run an economy will gradually approach a steady state equilibrium and ceases to grow and the only way to dampen the effects of diminishing returns and grow is through an infusion of technological progress (Solow, 1956). Hence the theory takes the long-run growth rate as exogenously given from the economic system.

Romer (1986) and Lucas (1988), through the endogenous growth model, challenged the view that the only way to grow an economy was through an infusion of technological progress and stressed that the long-run rate of economic growth is determined by investment decisions endogenous to the economic system. Investment refers to research and development expenditures and human capital formation, as healthy and educated workers would be able to use existing capital and technology more efficiently (Romer, 1986; Lucas 1988). Knowledge spill overs occur such that investment in knowledge by one firm increases the production potential of other firms. Gundlach (2001) specify that the theoretical foundation for the impact of human capital on economic growth takes its roots within the endogenous theory. Hence, like the Solow growth model, the endogenous growth model by Romer and Lucas also largely ignore the role of trade structure as a determinant of economic growth.

However, the theories of intra-industry trade in differentiated products consider trade structure as a growth determinant. These are the product cycle theory, overlapping demands theory and economies of scale theory. Linder (1961), in the overlapping demands theory, also known as spill over theory suggest 
that trade in manufactured goods is likely to be greatest among countries with similar tastes and income levels. In the process of satisfying the domestic market the nations acquire necessary experience and efficiency that enable them to subsequently export commodities to other nations with similar tastes and income levels (Linder, 1961).. However, contrary to the overlapping demands theory, developed and developing nations enjoy a growing amount of intra-industry trade since there are people with similar tastes and incomes in developing and developed countries (Sawyer and Sprinkle, 2004).

The product cycle theory by Vernon (1966) also explains intra-industry trade and accounts for the reasons for and duration of the technological gap between countries that trade. The theory suggests that industrialised countries are innovative, hence they specialise in producing newly invented goods based on technological innovations. When production is completely standardised and the product loses its distinctiveness for the innovating country, comparative advantage shifts from the innovating country to a country with cheap labour, hence production and export shifts from the developed country to the developing country. The developed country may then import the product from the developing country, hence intra-industry trade (Appleyard and Field, 2014).

The economies of scale theory also explain intra-industry trade, where economies of scale are a reduction in average costs that result from an increase in size of a firm's plant and equipment (Salvatore, 2013). With, increasing returns to scale, output grows at a rate that is proportionately more than the increase in factors of production. This can lead to greater division of labour and specialisation hence beneficial trade between nations that are identical (Salvatore, 2013). About a third of all goods-producing industries are characterized by increasing returns to scale and mutually beneficial trade can be based on these increasing returns to scale (Antweiler and Trefler, 2002).

\section{Empirical Literature}

Empirical literature suggests various determinants of economic growth in different countries. Most of the empirical work tests the significance of trade openness and trade volume to economic growth, thus, only a few studies have examined the empirical relationship between trade structure and economic growth. These include Lederman and Maloney (2003) who studied the influence of export concentration and intra-industry trade on economic growth. Results from the study proved that export concentration reduces growth by hampering productivity while intra-industry trade is associated with good growth performance.

Further, Kali et al., (2007) empirically tested the significance of number of trade partners and concentration of trade on the economic growth of a country. Standard Ordinary Least Squares and Fixed Effects regressions were used for the study and findings revealed that the structure of trade, independent from trade openness, contribute to economic growth. The study found a positive correlation between the number of trading partners and growth especially for rich countries and a positive correlation between trade concentration and growth especially for poor countries. Further, the relationship between intraindustry trade and economic growth was investigated, using the Panel Vector Autoregressive method for selected developed and developing countries for the period 2001-2014. The results showed that the relationship is positive for the developed countries and negative for the developing countries (Rasekhi and Ramezani, 2017).

Other studies on trade structure were carried out by Antweiler and Trefler (2002), who found out that a third of all goods-producing industries are characterized by increasing returns to scale, hence scale economies are a quantifiable and important source of comparative advantage and growth. Further, Basu and Das (2011) used the generalized kernel estimation methodology to examine the role played by skill and technology content of the exports so as to understand the differences in economic performance for eighty-eight developing countries over 1995 to 2007. Findings from the study suggested that as the skill and technology content of exports increased, the impact on GDP per capita increased positivity.

There are a number of studies that have tested the impact of different variables on economic growth including trade openness, trade volume and the standard explanatory variables used in this paper. These incluse Hossain and Mitra (2013), who examined the dynamic causal relationships between economic growth and five determinants, which are trade openness, foreign aid, domestic investment, long-term external debt and government spending for a panel of thirty three African countries for the period 1974 to 2009. A short-run bidirectional causality was found between economic growth and trade openness and 
the the long-run effects of trade openness, domestic investment and government spending on economic growth are significantly positive.

Further, Zahonogo (2017) investigated the impact of trade openness on economic growth in developing countries, using data from forty two sub-Saharan African countries for the period 1980 to 2012. A dynamic growth model was estimated using the pooled mean group estimation technique and findings suggested that sub-Saharan African countries can boost their economic growth through international trade by promoting trade openness. Anyanwu (2014) investigated the determinants of economic growth in Africa using an Africa-only sample with five non-overlapping three-year averages of cross-sectional data between 1996 and 2010. The results suggested that domestic investment, net ODA inflows, education, government effectiveness, urban population, and metal prices positively and significantly affect Africa's economic growth. A Bayesian Model was employed to find out the determinants of growth across countries and results suggested that education, trade and investment seemed to matter in recent growth periods (Bruns and Loannidis, 2020).

Boldeanu and Constantinescu (2015) highlighted the main factors that can determine economic growth as raging from public expenditure, openness and foreign direct investment. Further, Barro (2003) suggests that GDP per capita growth rate is enhanced by the rule of law, the investment ratio, favourable movements in terms of trade and increased international openness and it is negatively affected by fertility rate, ratio of government consumption to GDP and inflation rate. Higher education and international trade lead to an increase in economic growth in China while high fertility, high inflation, and the presence of state-owned enterprises (SOE) reduce growth rates among the provinces (Baizhu and Yi, 2000).

Other studies focused on entirely non trade variables in determination of economic growth. Ali (2012) investigated the factors that stimulated and maintained economic growth in Malaysia from the year 1997 to 2010 using time series analysis and found out that consumption price index, stock market index, export and housing price index were significant determinants. Futher studies on determinants of growth were carried out by Cuaresma, Doppelhofer and Feldkircher (2014) who investigated determinants of regional economic growth for European Union regions for the period 1995-2005 using Bayesian model averaging. The findings suggest that regions containing capital cities are growing faster, as do regions with a large share of workers with a higher education.

Empirical findings by Moral-Benito (2012) suggest that the most robust growth determinants are the price of investment goods, distance to major world cities, and political rights while Obwona (2002) suggest that FDI has a positive impact on GDP growth in Uganda. Choe (2003) tested the causal relationships between economic growth and FDI in 80 countries over the period 1971-95, using a panel VAR model and the results showed that FDI Granger-causes economic growth, and vice versa suggesting a strong positive association between economic growth and FDI inflows. Keun and Byung-Yeon (2009) studied the determinants of long-run economic growth by conducting cross-section estimations and fixedeffects panel and system-GMM estimations and found out that technology and tertiary education and institutions were the determinants of long-run economic growth.

The analysis has revealed that there is significant empirical literature on trade and economic growth and also on other determinants of economic growth. However, there is very little literature on trade structure and economic growth, especially for African countries. This paper therefore fills this gap by providing the impact of trade structure on growth of African economies. An analysis of the research methods employed follows in the next section.

\section{Research Methodology}

This section presents the methods that were employed in this paper to determine whether trade structure is an enabler of economic growth in Africa or not. The econometric model and estimation methods employed are discussed.

\section{Econometric Model}

An econometric estimation of panel data from the eighteen African countries is done. Our econometric specification follows Levine and Renelt (1992) whereby the rate of GDP growth is regressed against a set of explanatory variables that capture trade structure, a vector of standard explanatory variables and total trade. We introduce the variable of interest first, namely trade structure and the other 
variables now standard in the literature, to examine both robustness and suggestive channels of influence. The general equation for this paper is given as equation 1 .

$$
\mathrm{GDP}_{i t}=\beta_{0}+\beta_{1} \text { Trade Structure }_{i t}+\beta_{2} \text { Standard Explanatory Variables }_{i t}++u_{i t}
$$

.1

From the general equation, the specific equation is given as equation 2, where there the dependent variable, GDP ${ }_{i t}$ is the Gross Domestic Product growth of the African countries per year.

$$
\begin{aligned}
& \text { GDP }_{i t}=\beta_{0}+\beta_{1} \text { HH Index }_{i t}+\beta_{2} \text { IIT Index } \\
& \text { it } \\
& \beta_{4} \text { Gross capital formation }_{i t}+\beta_{3} \text { Inflation }_{i t}+\beta_{6} \text { Population growt }_{i t}+u_{i t}
\end{aligned}
$$

To measure intra-industry trade, we use the index by Grubel-Lloyd (1975), which provides a relatively reliable measure of intra-industry trade. The index is calculated as shown in equation 3 , where $\mathrm{Xi}$ is the value of exports and $\mathrm{Mi}$ is value of imports of good $\mathrm{i}$ and $\mathrm{X}-\mathrm{M}$ is an absolute value.

Intra-industry trade (IIT) Index $=1-(\mathrm{Xi}-\mathrm{Mi} / \mathrm{Xi}+\mathrm{Mi})$

The intra-industry trade index ranges from 0 , where there is no intra-industry trade to 1 , where $100 \%$ of trade is intra-industry trade. The weakness of the index is that one can get very different values depending on how one defines the industry or product group. The more broadly one defines the industry or product group, the more likely a country will engage in intra-industry trade (Sawyer and Sprinkle, 2004).

The Hirschman Herfindahl $(\mathrm{HH})$ index is used to measure concentration of trade. The index is calculated as shown on equation 4 .

$$
\mathrm{HH} \text { Index }=\sum_{J}^{N}\left(\frac{\mathrm{Tij}}{\Sigma_{j}^{N} \mathrm{Tij}_{\mathrm{j}}}\right) 2
$$

where $\mathrm{N}$ denotes the total number of trading partners and Tij is the total value of trade (exports plus imports) between countries $i$ and $j$. A country with trade that is concentrated in a very few markets will have an index value close to 1 while a country with a perfectly diversified trade portfolio will have an index close to zero (World Bank, 2019). This index is widely used in studies that focus on general indicators of economic concentration (Antweiler and Trefler 2002). The third trade structure variable of interest is the number of exported goods per year from all sectors of the eighteen African countries.

Data on the number of exported goods per country and the Hirschman Herfindahl $(\mathrm{HH})$ index were extracted from WITS World Bank indicators (2019). GDP growth, Gross capital formation, inflation and population growth were extracted from World Bank's World development indicators (2019). Data for computing the Grubel-Lloyd (1975) index of intra-industry trade (IIT) was also extracted from World Bank's World development indicators (2019).

\section{Estimation of the model}

This section explains how the model described is estimated. The Durbin - Wu - Hausman test is carried out to determine whether to use fixed or random effects estimation. Fixed effects are widely thought to be a more convincing tool for estimating, while random effects are used when as many time constant controls as possible are included amongst the explanatory variables (Wooldridge, 2006). The following is the hypothesis for the Durbin - Wu -Hausman test:

$H_{0}: \alpha_{i}$ are distributed independently of $X_{j}$

$H_{A}: \alpha_{i}$ are not distributed independently of $X_{j}$

Under the null hypothesis, the test statistic has a chi squared distribution. If the null hypothesis is not rejected, then both random and fixed effects are consistent. However, in that case the fixed effects becomes inefficient as it involves estimating unnecessary dummy variable coefficients and the random effects model should therefore be used (Dougherty, 2014). If the null hypothesis is rejected, it means 
random effects estimates are subject to unobserved heterogeneity bias and differ systematically from fixed effects estimates. and the fixed effects model should be used (Dougherty, 2014).

We then run the Hausman test to choose the best estimation technique between fixed and random effects. The results are presented on table 1.

\begin{tabular}{|l|l|l|l|}
\hline Test Summary & Chi-Sq. Statistic & Chi-Sq. d.f & Prob \\
\hline Cross-section random & 13.846677 & 6 & 0.0314 \\
\hline
\end{tabular}

Source: Author's own computation using data from World Bank's World Development Indicators (2019)

Table 1: Correlated Random Effects - Hausman Test

The results of the Hausman test indicate that the best estimation technique is the fixed effects. We therefore reject the null hypothesis and conclude that the fixed effects is the best estimator.

\section{Unit Root tests}

The Levin-Lin-Chu Test for unit root suggests the following hypothesis: $\mathrm{H}_{0}$ : each time series contains a unit root and alternatively $\mathrm{H}_{\mathrm{A}}$ : each time series is stationary. The Im-Pesaran-Shin (IPS) test is not as restrictive as the Levin-Lin-Chu test, since it allows for heterogeneous coefficients. The null hypothesis for the IPS test is that all individuals follow a unit root process that is: $H_{0}=\rho=0 \mathrm{Vi}$. The alternative hypothesis allows some (but not all) of the individuals to have unit roots: $H_{A}$ : $\rho i<0$ for $I=$ $1,2, \ldots \ldots N_{1}$ or $H_{A}: \rho i=0$ for $I=N_{1}+1, \ldots . . N$.

Using Levin, Lin, and Chu tests the results show that variables are stationary after first differencing except for GDP growth, inflation and population growth. However, under the Im, Pesaran and Shin stationarity tests, variables are stationary at levels except for number of exported products and HH index. Given these results, stationarity tests thus provide strong evidence of stationarity at level and first differences, allowing for estimation of the model.

\section{Diagnostic tests}

The diagnostic tests carried out are multicollinearity, wald test of joint significance and panel crosssection dependence test. The results showed no evidence of multicollinearity. The Wald test is used to find out if explanatory variables in the model are significant. If the Wald test shows that the parameters for certain explanatory variables are zero, the variable can be removed from the model. If the test shows the parameters are not zero, it can be included in the model. The null hypothesis is that variables are not jointly significant in explaining growth thus: $C(1)=C(2)=C(3)=C(4)=C(5)=C(6)=0$. Table 2 shows results from Wald Test of joint significance.

\begin{tabular}{|l|l|l|l|}
\hline Test Statistic & Value & Df & Probability \\
\hline F-statistic & 4.673189 & $(6,498)$ & 0.0001 \\
\hline Chi-square & 28.03914 & 6 & 0.0001 \\
\hline
\end{tabular}

Source: Authors' own computation using data from World Bank's World Development Indicators (2019)

Table 2: Wald Test of joint significance

We reject the null hypothesis based on the results of the Wald test and conclude that variables are jointly significant. The disturbances in panel data models are assumed to be cross-sectionally independent, but considerable evidence show that cross-sectional dependence is often present in panel regression settings. The problem of cross-sectional dependence is that it results in estimator efficiency loss and invalid test statistics. Hence, we carry out the panel cross-section dependence test. The null hypothesis is that no cross-section dependence may be stated in terms of the correlations between the disturbances in the different countries and it is stated as follows;

$$
H_{0} \rho_{i, j}=\operatorname{Corr}\left(u_{i, t}, u_{j, t}\right)=0 \text { for } i \neq j
$$

The results of the cross-section dependence tests presented on Table 3. 


\begin{tabular}{|l|l|l|l|}
\hline Test & Statistic & d.f & Prob. \\
\hline Breusch-Pagan LM & 171.2520 & 153 & 0.1486 \\
\hline Pesaran scaled LM & 1.043396 & & 0.2968 \\
\hline Bias-corrected scaled LM & 0.721967 & & 0.4703 \\
\hline Pesaran CD & 5.269479 & & 0.0000 \\
\hline
\end{tabular}

Source: Authors' own computation using data from World Bank's World Development Indicators (2019)

\section{Table 3: Panel Cross-Section Dependence Test Results}

The results on table 3 show that three out of four tests prove no serial correlation on residuals between the African countries. We therefore fail to reject the null hypothesis and conclude that there is no cross-section dependence on correlations between the disturbances in the eighteen African countries. The next section is an analysis of empirical results.

\section{Presentation and discussion of empirical results}

Even though fixed effects is the best estimator, based on the Durbin - Wu - Hausman test, we present results for both fixed and random effects estimations on table 4 to check for the robustness of the results.

\begin{tabular}{|l|l|l|}
\hline & Fixed Effects Coefficient & Random Effects Coefficient \\
\hline & & \\
\hline Trade Concentration & -2.302597 & -2.041327 \\
\hline Intra-industry trade & $7.633722^{* * *}$ & $8.449605^{* * *}$ \\
\hline Number of exported Products & $0.002160^{* *}$ & $0.002401^{* *}$ \\
\hline Gross fixed capital formation & $0.122346^{* * *}$ & $0.131268^{* * *}$ \\
\hline Inflation & $-0.001244^{* *}$ & $-0.009544^{* *}$ \\
\hline Population growth & $0.825857^{* *}$ & $0.466243^{* *}$ \\
\hline Constant & 2.651818 & \\
\hline$* * *$ & \\
$*$ & $* 0.01$ - statistical significance at 1\% level & \\
${ }^{* *} \mathrm{p}<0.05$ - statistical significance at 5\% level & \\
${ }^{*}<0.1$ - statistical significance at 10\% level &
\end{tabular}

Source: Authors' own computation using data from World Bank's World Development Indicators (2019)

\section{Table 4: Fixed Effects and Random Effects results}

The results from both fixed and random effects estimations are almost similar therefore proving their robustness. For interpretation however, we use results from the best estimator, fixed effects estimation. The results indicate that trade structure variables namely intra-industry trade and number of exported products are significant in enabling GDP growth with positive coefficients. This result suggests that a change in trade structure through an increase in intra-industry trade and number of exported products can lead to an increase in economic growth for African countries. We therefore reject the null hypothesis for these two trade structure variables. Our findings on intra-industry trade thus concur with empirical literature as Krugman (2015) notes that the scale economies arising from intra-industry trade lead to more rapid productivity gains and hence faster growth.

The results also show that the relationship between concentration of trade and GDP is inverse and not significant. We therefore fail to reject the null hypothesis for this trade structure variable. This finding concurs with the conclusion by Kali et al., (2007) that positive correlation between the number of trading partners and growth is especially pronounced in rich countries and African countries are not rich.

We reject the null hypothesis for the standard explanatory variables since they are statistically significant in enabling GDP growth. Our findings suggests that an increase in gross capital formation and population growth can lead to economic growth in Africa. The finding on gross capital formation concur with Romer (1986) and Lucas (1988) who stressed investment in the form of research and development expenditures as a determinant of long run growth. Similarly, Hossain and Mitra (2013) found that for African countries, domestic investment and economic growth are significantly positively related. Our findings on population growth however do not concur with some empirical literature as Barro (2003) suggests that GDP per capita growth is negatively affected by fertility rate. 
Further, the findings reveal that inflation is significant with an inverse relationship to GDP growth. An increase in inflation can therefore cause a fall in economic growth in Africa. Empirically, Barro (2003) suggests that GDP per capita growth is negatively affected by inflation rate while. Baizhu and Yi, (2000) also suggested that high inflation, reduces growth rates of economies.

\section{Conclusions}

We conclude that for African countries, trade structure positively determines economic growth. Holding other factors constant, an increase in intra-industry trade between countries can lead to economic growth as the countries benefit from specialisation and economies of scale. Similarly, an increase in the number of exported products leads to economic growth in Africa. However, an increase in number of trade partners has no effect on economic growth of African economies. Therefore, based on these findings, policy makers in African countries have a higher chance of realising growth in their countries if they focus more on increasing the number of exported products. Further, it makes economic sense for trade partners in Africa to put structures in place that promote the growth of intra-industry trade between them. A shift in trade policy making in Africa where trade structure, considering its growing importance, gets as much consideration as trade openness and trade volume may also enable African countries to realise faster economic growth.

We also conclude that economic growth of African countries is achieved when there is growth in domestic investment. This means that African economies can perform better if more funds are channelled towards investment. The positive relationship between economic growth and population growth suggest that as most African economies use labour intensive production techniques, growth in population can actually help to grow economies. However, care must be taken to ensure that the growth in population is sustainable given resources available in a country and it is necessary to ensure a skilled labour force. We conclude that inflation growth can retard the growth of African economies, thus it is in the best interest of the economies to keep inflation rate as low as possible.

\section{Limitations and direction for future research}

The limitations faced were that there was limited availability of data for some African countries hence we could not cover as many countries as desired in this paper. In future, research could focus on comparisons of trade structure and growth between different regions in Africa.

\section{References}

Antweiler, W. and Trefler, D. (2002) 'Increasing Returns and All That: A View from Trade', The American Economic Review vol. 92, No. 1. pp. 93-11.

Anyanwu J. C. (2014) Factors Affecting Economic Growth in Africa: Are There any Lessons from China? African Development Review, Wiley Online Library.

Appleyard, D.R. and Field, A. J. (2014) International Economics, Eighth edition, McGraw Hill/Irwin, New York.

Bahar, D. (2016) Diversification or specialization: What is the path to growth and development? Brookings.

Baizhu, C. and Yi, F. (2000) 'Determinants of economic growth in China: Private enterprise, education, and openness', China Economic Review, Elsevier, vol. 11(1), pages 1-15.

Balassa, B. (1965) 'Trade Liberalisation and Revealed Comparative Advantage', Newhaven, Yale University Economic Growth Centre.

Barro, R.J. (2003) 'Determinants of Economic Growth in a Panel of Countries', Annals of Economics and Finance, 4, 231274.

Basu, S.R. and Da,s M. (2011) Export structure and economic performance in developing countries: evidence from nonparametric methodology, policy issues in international trade and commodities: Economic and Social Commission for Asia and the Pacific United Nations, Study series No. 48.

Boldeanu F.T. and Constantinescu L (2015) Bulletin of the Transilvania University of Braşov Series V: Economic Sciences, Vol. 8 (57) No. 2. The main determinants affecting economic growth.

Bruns, S.B., and Loannidis J.P.A (2020) Determinants of economic growth: Different time different answer? Journal of Macroeconomics. Volume 63, March 2020, 103185. Elsevier.

Cuaresma, J.C., Doppelhofer, G. and Feldkircher, M. (2014) 'The Determinants of Economic Growth in European Regions', Regional Studies, 48:1.

Choe, J.I. (2003) 'Do Foreign Direct Investment and Gross Domestic Investment Promote Economic Growth', Review of Development Economics, Wiley Online Library 7(1), 44-57.

Dougherty, C. (2014) Introduction to Econometrics, $4^{\text {th }}$ edition. Oxford University Press, Great Britain. 
Gujarati, D.N. (2005) Basic Econometrics, $4^{\text {th }}$ edition. McGraw-Hill Higher Education, International Edition, New York.

Levine, R. and Renelt D. (1992), 'A sensitivity analysis of cross-country growth regressions', American Economic Review, 82(4):942-963.

Linder, S.B. (1961) 'An Essay on Trade and Transformation', Hoboken, NJ: John Wiley and Sons.

Lucas, R.E. (1988) 'On the Mechanics of Economic Development', Journal of Monetary Economics, Volume 22, Issue 1, Pages 3-42.

Frankel, J.A., Stein, E. and Wei, S.J. (1995), 'Trading blocs and the Americas: the natural, the unnatural, and the supernatural', Journal of Development Economics, 47(1), pp. 61-95.

Gregorio, J. (1992) 'Economic growth in Latin America', Journal of Development Economics, Volume 39, Issue 1.

Grossman, G. and Helpman, E. (1991) 'Innovation and Growth in the Global Economy' Cambridge, MA: The MIT Press.

Grubel, H.G. and Lloyd, P.J. (1975) 'Intra-Industry Trade: The Theory and Measurement of International Trade in Differentiated Products', Macmillan Press, London.

Gundlach, E. (2001) 'Education and economic development: An empirical perspective', Journal of Economic Development, 26(1), 1-24.

Hossain, S. and Mitra, R. (2013) 'Foreign aid and economic growth in the Philippines', Economics Bulletin, Volume 33, issue 3, 1706-1714.

Kali, R., Méndez, F. and Reyes, J. (2007) 'Trade structure and economic growth', Journal of International Trade $\mathcal{E}$ Economic Development, An International and Comparative Review, Volume 16, Issue 2 16:2, 245-269.

Keun, L. and Byung-Yeon, K. (2009) 'Both Institutions and Policies Matter but Differently for Different Income Groups of Countries: Determinants of Long-Run Economic Growth Revisited', World Development, Volume 37, Issue 3.

Krugman, P.R., Obstefeld, M. and Melitz M.J. (2015) International Economics: Theory and Policy, 10 th edition: Pearson, Global edition ore-book, USA.

Lederman, D. and Maloney W.F. (2003) R\&D and Development, Policy Research Working Paper No. 3024. World Bank, Washington, DC.

Menon, J.T. and Dixon P.B. (1996) 'How Important is Intra-industry Trade in Trade Growth?', Open economies review 7, Kluwer Academic Publishers, The Netherlands.

Moral-Benito, E. (2012) 'Determinants of Economic Growth: A Bayesian Panel Data Approach' The Review of Economics and Statistics 94:2, 566-579, The MIT Press.

Obwona, M.B. (2002) 'Determinants of FDI and their Impact on Economic Growth in Uganda' African Development Review, Volume13, Issue 1, Wiley Online library.

Rasekhi, S. and Ramezani M. (2017). The Nexus between Economic Growth and Intra-Industry Trade. International Journal of Business and Development Studies Vol. 9, No. 1, pp 47-66.

Rodriguez, F. and Rodrik, D. (2001) 'Trade Policy and Economic Growth: A Skeptic's Guide to the Cross-National Evidence', University of Maryland and Harvard University.

Romer, P.M. (1986) 'Increasing Returns and Long Run Growth' Journal of Political Economy, 94. 1002 -1037.

Salvatore, D. (2013) International Economics, $11^{\text {th }}$ edition, Wiley International Edition, United States of America.

Sawyer, W.C. and Sprinkle, R.L. (2004) 'International Economics', Prentice Hall of India, New Delhi.

Solow, R.M. (1956) 'A Contribution to the Theory of Economic Growth', Quarterly Journal of Economics 70, The MIT Press.

UNCTAD (2016) Key indicators and trends in international trade, a bad year for world trade? Available on https://unctad.org/en/PublicationsLibrary/ditctab2016d3_en.pdf

UNDP (2015) Export Dependence and Export Concentration. Towards Human Resilience: Sustaining MDG Progress in an Age of Economic Uncertainty.

Vernon, R. (1966) 'International investment and international trade in the product cycle' The Quarterly Journal of Economics, Vol. 80 No. 2, pp. 190-207: Oxford Academic.

Wooldridge, J.M. (2006) Introductory Econometrics, A Modern Approach. Third Edition, Thomson South Western. Canada.

World Bank (2019). World Development Indicators https://databank.worldbank.org/source/world-developmentindicators\# (Accessed 20 August 2019).

Zahonogo P. (2017)Trade and economic growth in developing countries: Evidence from sub-Saharan Africa. Journal of African Trade Volume 3, Issues 1-2, December 2016, Pages 41-56. Elsevier 